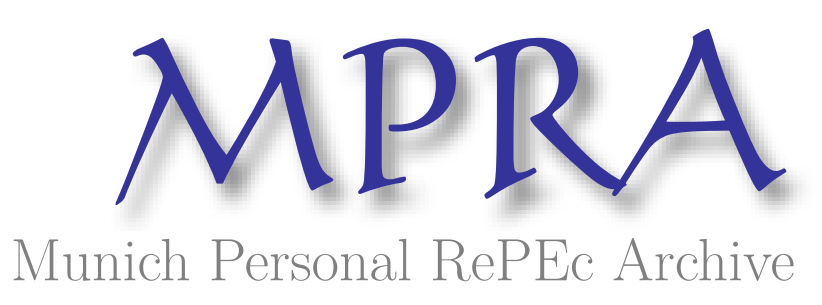

\title{
Rebuttal of Dr. Usamah Uthman's Review in Global Finance Journal No 22 (2011) pp 80-81 1.
}

ramady, Mohamed

king fahd university of petroleum and minerals

2013

Online at https://mpra.ub.uni-muenchen.de/48333/

MPRA Paper No. 48333, posted 15 Jul 2013 14:33 UTC 


\section{Rebuttal of Dr. Usamah Uthman's Review in Global Finance Journal No 22 (2011) pp 80-81 is}

1. The reviewer's definition of business cycles is correct in terms of actual vs. potential GDP during booms and recessions. Figure 2.2 indicates exactly these swings for different eras of Saudi GDP, and not income flows. The different underlying reasons for this volatility are explained. Figure 2.3 demonstrates the clear inter-relationships of all three factors affecting Saudi Arabian economy (govt. expenditure, oil revenues, and flows into savings/investments), as well as the important element of foreign owned factor resources (remittances) affecting the Saudi economy. The table that follows illustrates the actual magnitude of such remittance flows, which is also another unique feature of the Saudi economy, in comparison to Saudi population, GDP and other countries with large foreign labor force.

2. SAMA's stated goals are explicitly set out by the institution and captured in Figure 4.4. SAMA's goals are not reducing unemployment and GDP management, but these are the goals of the Ministry of Finance as any observer of the Saudi economy should know. Fiscal policy, and influencing GDP/unemployment are the stated goals of the Ministry of Finance and stated in the book. Concerning "domestic money creation process" Figure 4.8 explains this process, as the Saudi Riyal is a fiat currency that is created only by virtue of dollar/foreign reserve creation, and not through SAMA printing SR notes or the creation of money supply without backing of foreign reserves. It is the Saudi budgetary mechanism (injections) into the system, and the resultant SR equivalent of dollar assets that are created, that is the prime operating mechanism for money creation. Conversely, Saudi Riyals are extinguished out of the system when SR are converted into dollars and transmitted outside the Kingdom. The Saudi economy is not a closed one (p.82). Bank's deposits are generated primarily from government expenditures which flow into the accounts of the private sector. Table 4.5 (p.95) expressly highlights the overwhelming importance of the net domestic flows through government spending, as opposed to commercial bank's claims on the private sector in the analysis of factors affecting the changes in broad Money Supply M3 in Saudi Arabia. SAMA has gradually evolved certain primary responsibilities for itself, as well as asserting its independence in the use of certain monetary tools, and shared others with the Ministry of Finance (pp.78-79, 83). SAMA has indeed been operating on money-supply rule (changes in required reserves, deposit to loan ratios, setting repo and reverse-repo rates), as opposed to an interest-rate rule due to its fixed exchange rate policy. There are different strands of opinion on the effectiveness of fixed as opposed to floating exchange rates, and these are explored in the book (Table 4.2, p. 89). SAMA's official stated policy has been to remain fixed to the US dollar (p. 89) and it has intervened through swap facilities where necessary when speculative pressure on the SR has emerged. The reviewer alludes to Saudi twin deficits.

\footnotetext{
Mohamed A. Ramadv (2010). The Saudi Arabian Economy: Policies, Achievements, and Challenges. Second Edition. Springer, Pp. xxii - 512. ISBN 978-1-1419-5986-7.

DOI of original article: http://dx.doi.org/10.1016/j.gfj.2011.05.007.
} 
Twin deficits occur when countries run both a current account deficit and a budget deficit. Saudi Arabia has not had a current account deficit since 1999 and this is illustrated in the book (Figure 3.1, page 46). As such, the issue of twin deficit, on a recurrent basis, as is the case for the USA, is not a characteristic of the Saudi economy.

4. Capital Markets. The Saudi stock market and its supervision, as well as any shared responsibilities with other regulators, are important issues. The change in the regulatory aspects of the Saudi stock market have been extensively highlighted, especially the application of rules, disclosures and listings (pp. 150-152, 154). The observed deficiencies and inherent regulatory biases of the Capital Market Authority (CMA) are also explored, but not mentioned by the Reviewer. (pp. 155, 157-158).

3. Stock market volatility and performance. The performance of the Saudi Stock market and the overheating of the market are mentioned in detail (p. 166, 167, 168). The chapter explores the performance of individual investors vs. institutional/corporate players, as well as the high $\mathrm{P} / \mathrm{E}$ ratios and asset bubble issue reached in February 2006 prior to the crash (p.163). The Chapter explains the different theoretical concepts of investor behavior (irrational exuberance and herd mentality) and highlights whether the Saudi market exhibits weak-form efficiency, semi-strong efficiency or strong form efficiency as per economic theory (pp. 165-168). The different ways that Saudi investors behaved are explored in detail to explain the erratic nature of the Saudi stock market (pp. 166, 167).

4. Role of Islamic banks. There are no Islamic banks operating under their "Islamic name" in Saudi Arabia, as SAMA adopts a fit and proper bank supervisory policy and this is highlighted in the SAMA chapter. This in contrast with neighboring Gulf countries, that allow the establishment of Islamic banks. The Author has highlighted the growing importance of Islamic finance in Saudi Arabia, as well as the tendency for some of the licensed banks to convert some of their retail branches into Islamic branches as well as the launch of Shariah compliant mutual funds and issuance of Islamic bonds or Sukuks for mega project financing, such as Saudi Aramco and Sabic's Sukuk issuances.

5. Zakat. The Saudi government does not incorporate zakat collection in its budgetary forecasts for revenue and expenditures, but that zakat revenues are transferred directly to the Ministry of Social Affairs for charitable payments. The issue of a more efficient zakat collection system is highlighted in the Chapter (Table 3.8, p. 68), as an item of the Author's recommended proposals to enhance the revenue system for Saudi Arabia. There are different Islamic schools of thought (Hanbali, Shafi) which hold differing views on the concept of zakat i.e. whether Islamic obligations precede application, or whether application precedes Islamic obligations.

6. The debate on land speculation, real estate housing shortage and the impact of Saudi inflation are topics that can be expanded upon in later editions, although the issue of real estate's contribution to Saudi inflation has been highlighted in the book, as well as the social impact of inflation (Figure 4.10, pp. 100-101).

7. Hajj and Umrah. Until the late 1960s, Hajj revenues were an important element of the Saudi State's revenue, but since the 1970s the revenue derived from Hajj has been an insignificant source compared to hydrocarbon and other revenues. This is highlighted in the Public Finance Chapter. The Hajj/Umrah benefits are mostly localized in the Western Region and a few cities where religion visitors are allowed to travel. The Saudi government's expenditures on Hajj facilities far outweigh the benefits directly accruing to the government, as opposed to the Saudi retail/private sector.

8. Cost of unemployment. Concerning the natural rate of unemployment estimation, the Author has used average size of families' data from the Ministry of Social Affairs as well as population family size censuses to arrive at the rate of natural unemployment, especially for extended family support for those out of work. In KSA, families tend to be larger and extended families also provide support, as a formal "signing up" system for unemployment benefits was not operating as a government policy at the time of publication. As such, Saudi national rate of unemployment tends to be higher compared with countries that have a formal system of unemployment benefit registration. The book highlights the Saudi phenomenon of voluntary "educated unemployed" dealt (pp.382-383), as being unique to resource rich countries such as Saudi Arabia, where educated youth remain voluntarily unemployed upon returning back from international scholarships in the hope of obtaining higher paid Government or resource based jobs, and preferring not to take up available, but less "socially desired" jobs, thus leading to further "natural rate of unemployment" discussed earlier. This is unlike countries such as Lebanon, Jordan etc. where youth try to obtain higher education to obtain better jobs abroad, leading to a brain drain and a further cycle of more youth emulating their predecessor's success. According to a classical view of the market, buyers and sellers find one another immediately, without cost, and have perfect information about the prices of all goods and services. But this is not what happens in the 
real world, and that, as a consequence, stubborn unemployment will decline slowly. The policy implication is that in societies where unemployment benefits are paid, the State can use reductions in such benefits to force those unemployed back into available jobs. In Saudi Arabia, with no such schemes in place (at time of writing), only moral suasion and the lack of extended family support will drive unemployed educated/non educated youth back into the labor market to seek lower than hoped for available jobs. Concerning using "Okun's Law" to derive potential GDP losses due to unemployment, it is agreed that Okun's initial studies relate to the U.S. economy and is an empirical relationship. The Author's attempt is to try and estimate the potential GDP losses for the Saudi economy using the same empirical relationship, as well as official government unemployment data (for males only) as a starting base and extrapolate forward.

9. The methodologies used by the Author in trying to estimate the unemployment level for the period 2003-2013, are the ones used by economic statisticians. Starting off from the official government unemployment level (for males only) in 2008 at $9.8 \%$, the Author has used a forward looking labor supply model that takes into account NEW entrants into the labor market at different levels of schooling, after allowing for dropouts who might enter the labor force prior to graduation at each school level stage. This is the rate of new labor entrants to existing labor supply, with deductions made for those reaching retirement age, and for those who died. Given the relatively young age profile of the Saudi population, the number of new entrants far exceeds those reaching retirement in the period under question. At the same time, the Author has used the official government forecast for PLANNED new job generation by the private sector to absorb forecasted new labor supply entrants. The resultant gap between expected new private sector job creation (the Govt. sector has remained static in terms of incremental new job creation as discussed in the book), and labor entrants, is the forecasted unemployment rate for males only.

10. WTO accession impact. The Saudi post-WTO accession time frame for complying with its 2005 accession commitments, whereby the full cost and benefits will only become evident after 2010 for the majority of Saudi goods and services, i.e. after an average of 5 year grace period for most items is a key factor. Table 10.4 (pp. 303-309) sets out in great detail the potential impact on a wide sector of Saudi industry and services as to the likelihood of full WTO impact, once accession commitments are fully implemented. Even after 2010, full accession impact might not be felt due to the global financial crisis and the economic downturn felt in many countries competing with Saudi goods and services. As for the WTO's impact on Saudi economic growth and unemployment, pp. 316-317 set out the post-WTO accession agreement governing the issue of "Saudization" and the concept of "national treatment" labor exemptions that the Kingdom obtained in this regard.

11. GCC Monetary Union: The implications for a GCC monetary union, following the Euro and global financial crisis are spelled out as well as the lessons learned from the EU experience, especially in avoiding speculative attacks against a new bloc currency(p.464, 466, 470). EU convergence criteria and GCC compliance are explored in Table 14.13 (p. 467), along with recommendations for a GCC wide effort to enhance such convergence and set out on p. 458. The issue of Dubai and the fallout from its crisis on the GCC is examined in several areas: (p. 433, impact; p. 445 international contagion). As the Author argues, the prospect for monetary union, as opposed to currency union, is more promising for the GCC given the global fallout from the recent financial crisis, the withdrawal of Oman and UAE from the common currency, and the weakened Euro and lack of consensus on whether to tie the unified currency either to the dollar or to a basket of currencies (pp. 458-459, pp. 467-470). 